\title{
The Impact of Occupant Behavior on Daylight Performance of an Office Room in a Tropical Climate
}

\author{
Juliana Portela Vilar de Carvalho, Viviane Diniz Hazboun, Allyson Santos Carvalho and Aldomar Pedrini \\ Departamento de Pós-graduação em Arquitetura e Urbanismo, Universidade Federal do Rio Grande do Norte (UFRN), Natal, \\ 59079970, Brazil
}

\begin{abstract}
This work explores three patterns of occupants' control of window blinds and the potential influence on daylight performance of an office room in a tropical climate. In this climate, windows are frequently obstructed by curtains to avoid glare, despite the daylighting and the exterior view. The consequences are obstructed outside view, poor daylight quality and dependency on artificial lighting. This paper assesses the impact on available daylight using parametric analysis based on daylighting dynamic computer simulations using Grasshopper and Daysim software, combining WWR (window-to-wall ratio) (40\% and 80\%), SVF (sky view factor) (small and large) and occupant behavior (active, intermediate and passive users). The user patterns are based in an office buildings survey that identifies preferences concerning daylight use and control of shading devices. The daylight performance criteria combine UDI (useful daylight illuminance) (500-5,000 lux) and illuminance uniformity distribution. Results confirm the impact of occupant behavior on daylighting performance. The optimum combination of external shading devices, high SVF and high window size results in a useful daylighting for $1 / 3$ of the time for passive users and $2 / 3$ for active users.
\end{abstract}

Key words: Daylighting, occupant behavior, fenestration systems.

\section{Introduction}

This paper aims to assess the impact of occupants' control behavior on fenestration systems in daylight performance of office buildings in a tropical climate.

Occupant behavior plays a significant role on daylight performance of office buildings [1-5] which depends on presence, actions and occupancy profile [6]. The performance optimization emerges as a double challenge, which depends on technical and human requirements $[5,7]$.

Over the last few decades, many studies have focused on bridging the gap between the energy performance of predicted and real buildings, increasing the importance about the user behavior [3, 7]. The complicating factor is the uncertainty of actual interaction and diversity of occupant profiles [8], which includes passive and active users. Each occupant behavior pattern requires different technical

Corresponding author: Aldomar Pedrini, Ph.D., Sênior lecturer, research fields: built environment and daylight performance. solution for the building systems, which may affect the interactions between them [4].

Active users have significant impact on comfort and energy demand of a building when compared with passive users [8-10]. The impact results from the control action on the building systems [11]. The active behavior can increase annual daylight availability ratio by $20 \%$ and reduce by $50 \%$ the annual cooling energy demand [12].

The motivation drivers to control the building systems are not limited to physiological aspects, and are also based on the environmental psychology studies [5]. Maslow's hierarchy of needs [13] categorizes human basic needs that conduct the human actions in:

- Physiological needs: human body needs;

- Safety needs: human security need in system interaction displacement;

- Love needs: love and affection meaning the belonging sense, the autonomy and referring to the collectivity that may cause the social pressure; 
- Esteem needs: self-esteem related to the workplace personalization, the feeling of being good the "desire of recognition";

- Need for self-actualization: professional improvement.

Normally the behavioral model is represented by static models [14], based on outside impact factors (comfort, culture and economy), psychological, physiological, economy factors and the user behavior on energy performance [15]. The adaptive user behavior control is considered one of the gaps in the behavioral model. "The combination and interaction of multiple influencing factors, behaviors and occupants will fill the gap between academic research and simulation applications of occupant behavior" [4].

The behavioral models in building performance simulation often focus on the manual opening windows and lighting control, including the operation of shading devices. Hong et al. [7] proposed a "Drivers-needs-actions-systems" framework (DNAs framework) to formalize the modelling of energy-related occupant behavior, using four components: drivers, needs, actions and systems. The drivers stimulate the users into "physical, physiological and psychological needs". The needs refer to occupants' "physical and non-physical requirements". The actions are the interactions with systems to establish "environmental comfort". The systems are the equipments to "restore the environmental comfort" [16]. Reinhart and Voss [8] present an approach that mimics manual lighting and blind control in private offices, called Lightswitch. The algorithm is based on direct sunlight above 50 $\mathrm{W} / \mathrm{m}^{2}$, which induces the control when the occupant arrives or leaves the room.

External devices, including blinds, louvers and overhangs, are commonly indicated to tropical climates, due the excessive solar radiation (direct and diffuse) and overheating. When properly designed, they can prevent glare and direct radiation [17-20], decreasing the use of internal blinds, which are inefficient for external view, lighting and thermal performance.

Previous studies on daylighting evaluation in tropical climates [21-24] show the importance of using shading devices to optimize the performance. The optimum daylight performance is achieved using correlation between WWR (window-to-wall ratio) and SVF (sky view factor): low WWR (e.g. 20\%) requires a high SVF to reach $3 \mathrm{~m}$ depth; middle WWR (e.g. $40-60 \%$ ) must be totally shaded and combined with a low or intermediate SVF to reach $6 \mathrm{~m}$ depth; high WWR (e.g. 80\%-90\%) must be completely shaded and combined with a low SVF to reach $6 \mathrm{~m}$ depth.

\section{Method and Materials}

Parametric analyses of office rooms and daylight simulation are carried out to identify the impact of user behavior in models with different combinations of WWR and VSF, based on a field survey.

\subsection{The Occupant's Survey}

The survey was developed to identify how and why occupants interact with the fenestration system. The survey explores user preferences and their interactions with the shading systems, with questions about daylighting, daylight preferences intensity, opening and closing causes and the control frequency. The concept was based on DNAs framework [25].

The multiple-choice questionnaire was answered by 102 occupants of five office buildings, selected due to the daylighting potential.

\subsection{Simulation}

A base case is determined based on the field survey, with $5.00 \mathrm{~m}$ large, $7.00 \mathrm{~m}$ depth, single window orientated to the East, and internal surfaces light reflectance in accordance with national code (Table 1). The sensors distribution was designed according to Brazilian Code Standard [26] (Fig. 2), and six zones are characterized, related with the room depth. 


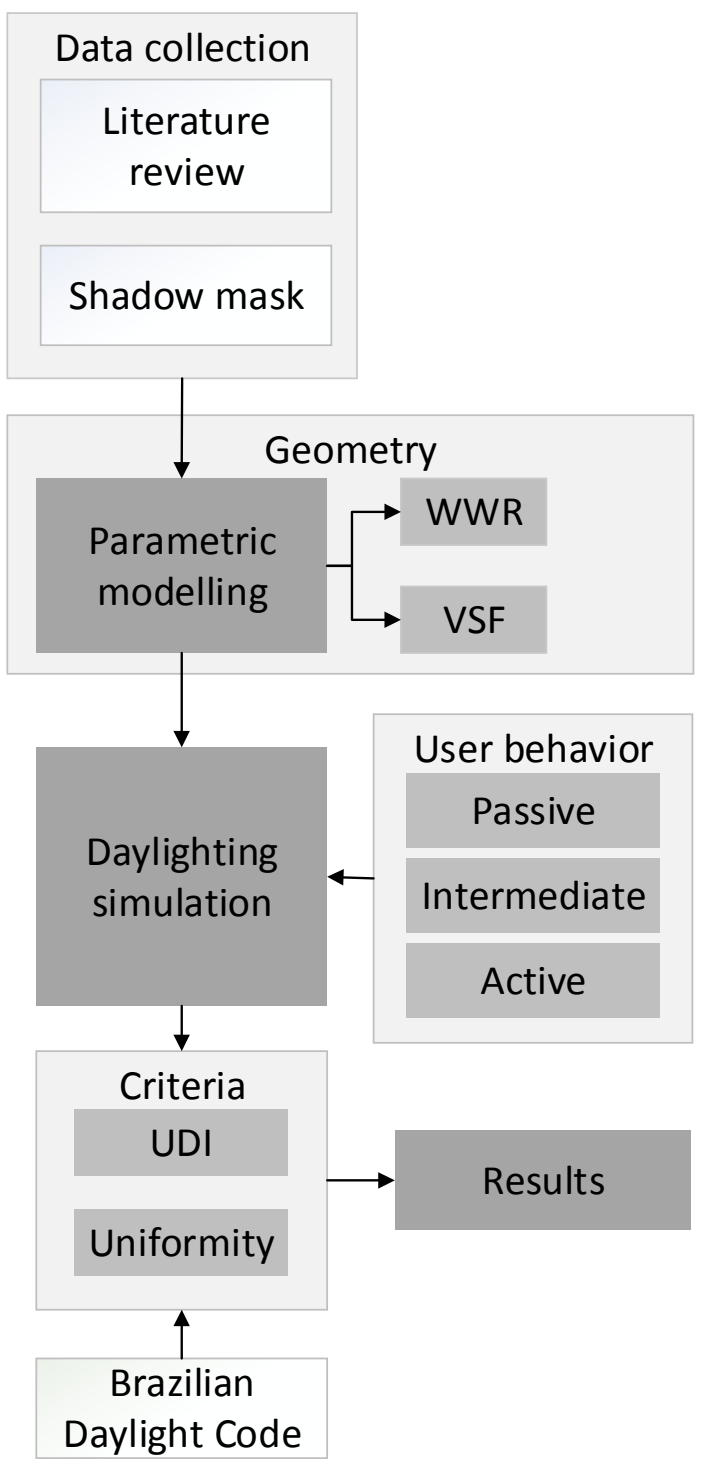

Fig. 1 Procedures.

Table 1 Reflectance of internal surface.

\begin{tabular}{ll}
\hline Elements & Light reflectance \\
\hline Ceiling & $0.6-0.9$ \\
Wall & $0.3-0.8$ \\
Work plane & $0.2-0.6$ \\
Floor & $0.1-0.5$ \\
\hline
\end{tabular}

The simulations comprise combinations of two window sizes (40 and 80\% WWR) and two SVF (low and high), with horizontal overhang $1.5 \mathrm{~m}$ depth and external blinds (Figs. 3 and 4). The SVFs were calculated in Ecotect software shadow masks [27], and the geometry was parametrically modelled in Grasshopper/Rhinoceros [28] and simulated in

\section{Daysim [29].}

The hourly simulation results, from 8 am to $4 \mathrm{pm}$, were classified and organized in an electronic spreadsheet to determine the adapted UDI (useful daylight illuminance) occurrences, between 500-5,000 lux, with comfortable illuminance uniformity (below $1 / 10$ ratio). Three user profiles-active, passive and 


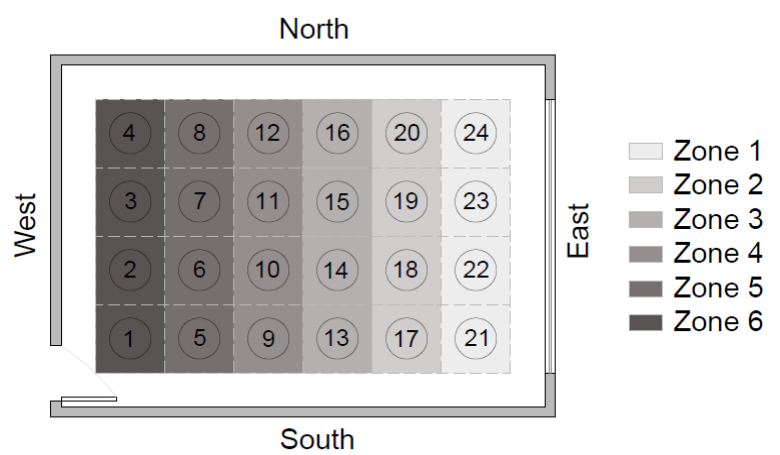

Fig. 2 Sensors and zones distribution.

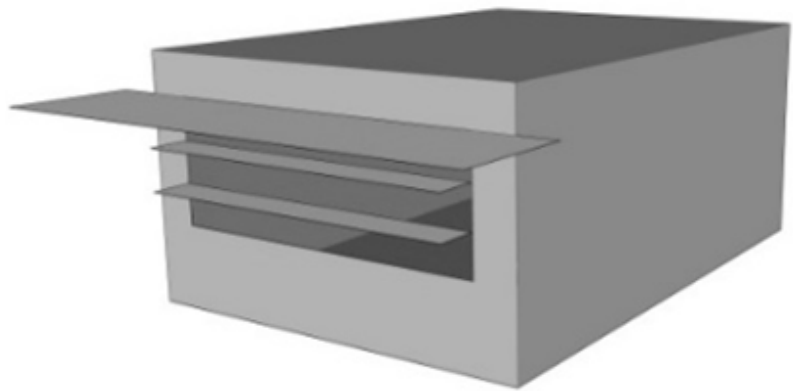

Fig. 3 Exterior shading for $40 \%$ WWR.

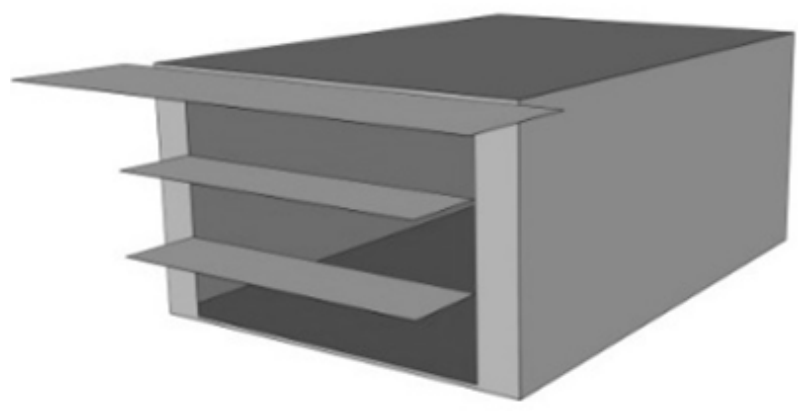

Fig. 4 Exterior shading for $80 \%$ WWR.

intermediate users - are defined to filter the daylight use in relation to the daylighting potential.

The analysis focuses on UDI graphics to compare the performance in relation to the room depth, and occurrence of illuminance uniformity to indicate no glare occurrence.

\section{Results and Discussions}

\subsection{The Occupant's Survey}

Only $47 \%$ of the occupants use daylight: $29 \%$ all day, $13 \%$ only at morning and $5 \%$ only in the afternoon (Fig. 5). The majority of the buildings occupants $(53 \%)$ do not use daylight, despite finding it stimulating and relaxing.

Curtains or blinds are primarily closed to control computer and VDT (visual display terminals) contrast $(19 \%)$, to prevent glare (18\%) and heat excess (13\%). Others drivers with smaller impact are privacy and no view contact (Fig. 6).

Curtains or blinds are usually opened to improve daylight performance (42\%) and to maintain visual contact to the outside $(33 \%)$. The complement of artificial lighting has a small impact (8\%).

The frequency of interaction varied between: "never interact" (55\%), "along the day, one or two per 
Morning $\square$ Afternoon $\square$ All day $\square$ Do not open

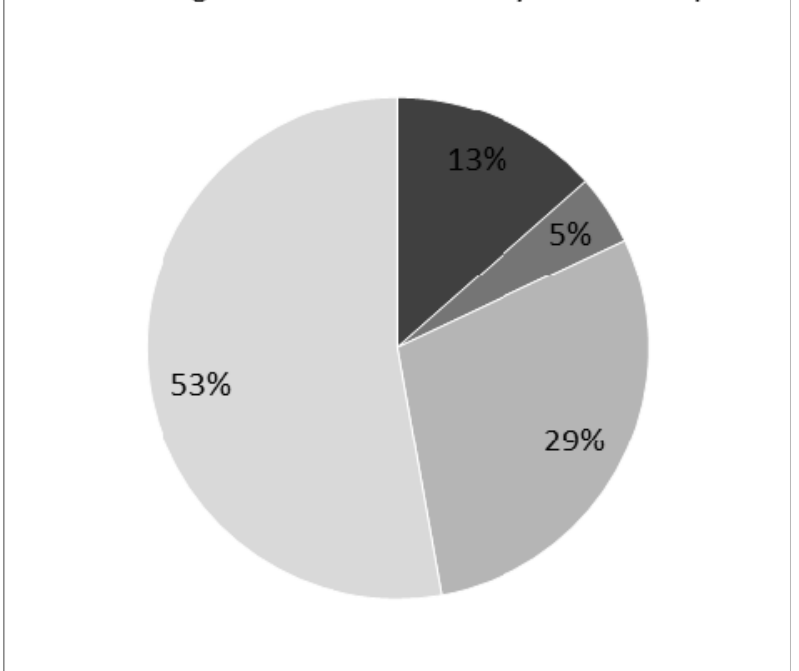

Fig. 5 Users' preference for daylighting.

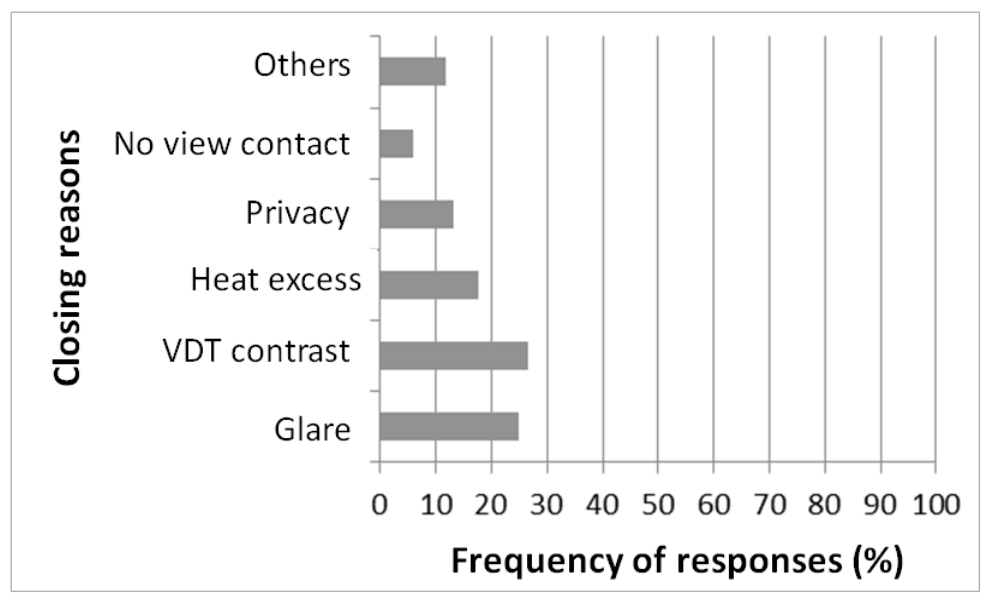

Fig. 6 Causes of daylighting restriction.

day" (22\%), "only in arrival and/or departure" (13\%) and "more than two per day" $(3 \%)$.

Three patterns of occupant behavior were determined, based on daylight use, preferences of users, motivations to open and close the shading devices, and frequency of interaction:

(1) Passive user: the occupant ignores the daylighting, turning the artificial light on and closing the blind when the room is uncomfortable. The occupant does not open the blinds anymore during the same day.

(2) Intermediate user: the occupant ignores the daylighting turning the artificial light on and closing the blind when the room is uncomfortable. The occupant does not open the blinds during that specific period, and take the control action just when it returns to the room.

(3) Active user: the occupant closes the blinds when the room is uncomfortable and opens the blinds when the available daylight does not cause discomfort. The control is similar to an automatic system.

\subsection{Daylight Simulation}

The results (Figs. 7 and 8) confirm the almost complete lack of daylighting use for passive users. They close the shading devices since the early hours of 

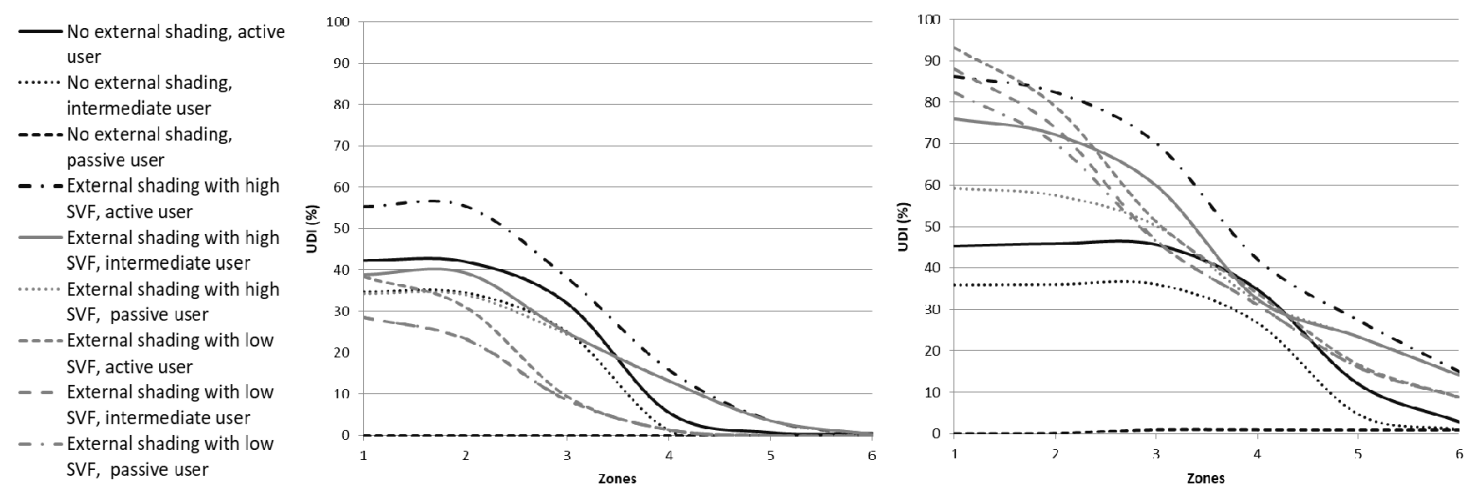

Fig. 7 UDI for $40 \%$ and $80 \%$ WWR.

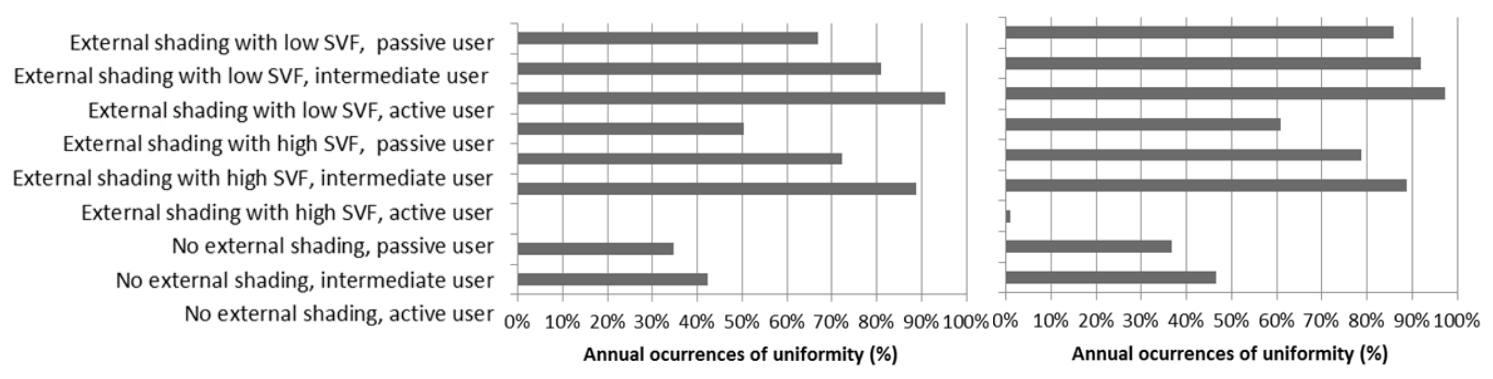

Fig. 8 Occurrences of uniformity for $40 \%$ and $80 \%$ WWR.

day due the penetration of direct solar radiation, high levels of illuminance and unsatisfactory uniformity of daylight, and do not open it to use the potential of daylight along the day. The maximum daylight performance occurs for active users, high SVF and hight WWR. Low WWR with exterior shading causes lack of illuminance or unsatisfactory uniformity.

Intermediate user in rooms without shading uses daylighting at afternoon when the blinds are opened after lunch, with approximately $35 \%$ of occurrence for both window sizes, reaching the second zone depth for $40 \% \mathrm{WWR}$ and third zone depth for $80 \% \mathrm{WWR}$.

The difference between intermediate and active user for room without exterior shading is attributed to the available daylight at later morning hours, which can improve to approximately $10 \%$ of daily use.

In models with external shading, increasing the $\mathrm{SVF}$, the performance increases more noticeable in 40\% WWR models and 80\% WWR models with active user. Increasing windows size and SVF also increases the zone depth performance.

The best performing model at zone 1 has external shading with low VSF and active control, presenting an occurrence of uniformity of $95 \%$ for WWR $40 \%$ and $97 \%$ for WWR $80 \%$. In this case, the impact of user behavior is more significant with a small WWR. Differences that occur between active and passive users are $30 \%$ with a WWR $40 \%$ and $10 \%$ for WW $80 \%$.

In scenarios with high VSF, the influence of user behavior is more noticeable. For WWR $40 \%$, there is an occurrence of $88 \%$ for active users and $50 \%$ for passive users. For WWR $80 \%$, active users promoted $88 \%$ of uniformity and passive users, $60 \%$.

\section{Conclusions}

The use of daylight is highly influenced by the user behavior when the exterior daylighting is abundant. The unsatisfactory performance in the early hours demands adjustments that block the daylighting, leaving the user without further discomfort stimulus to new adjustments to use daylight. The intermediate user could beneficiate from the lunch break to get a stimulus to open the blinds. The active user (more 
hypothetical than real) could represent someone very attentive and connected with the exterior. Nonetheless, these results also demonstrated the importance of a blind automatic control, which could result in daylight use for most of the time at the three zones close to the window.

The architectural characteristics of window size, external shading and SVF play a major influence on daylighting performance. In combination with an active user or automatic blind control, they can make daylighting useful for $2 / 3$ of the time for the first half of the room.

The user behavior modelling requires more refinement in future developments, including glare perception and intermediate shading adjustments.

\section{Acknowledgments}

This research has been sponsored by the $\mathrm{CNPq}$ (National Council for Scientific and Technological Development) and CAPES (Coordination of Superior Level Staff Improvement).

\section{References}

[1] Foster, M., and Oreszczyn, T. 2001. "Occupant Control of Passive Systems: The Use of Venetian Blinds." Building and Environment 36: 149-55.

[2] Mahdavi, A., Mohammadi, A., Kabir, E., and Lambeva, L. 2008. "Occupants' Operation of Lighting and Shading Systems in Office Buildings.” J. Build. Perform Simul. 1 (1): 57-65.

[3] Fabi, V., Andersen, R. V., Corgnati, S. P., Olesen, B. W., and Filippi, M. 2011. "Description of Occupant Behaviour 1 in Building Energy Simulation: State-of-art and Concepts for Improvements." In Proceedings of 12th Conference of International Building Performance Simulation Association, 2882-9.

[4] Yan, D., O’Brien, W., Hong, T., Feng, X., Burak Gunay, H., Tahmasebi, F., and Mahdavi, A. 2015. "Occupant Behavior Modeling for Building Performance Simulation: Current State and Future Challenges." Energy and Buildings 107: 264-78.

[5] D’OCA, S., et al. 2016. Introduction to an Occupant Behavior Motivation Survey Framework. Clima: Dinamarca.

[6] Rijal, H. B., Tuohy, P., and Humphreys, M. A. 2007. "Using Results from Field Surveys to Predict the Effect of Open Windows on Thermal Comfort and Energy Use in Buildings." Energy and building 39: 823-36.

[7] Hong, T., et al. 2015. "An Ontology to Represent Energy-related Occupant Behavior in buildings. Part II: Implementation of the DNAS Framework Using an XML Schema." Building and Environment: 196-205.

[8] Reinhart, C., and Voss, K. 2003. "Monitoring Manual Control of Electric Lighting and Blinds." Lighting Res. Technol. 35 (3): 243-60.

[9] Bourgeois, D., Reinhart, C., and Macdonald, I. 2006. "Adding Advanced Behavioural Models in Whole Building Energy Simulation: A Study on the Total Energy Impact of Manual and Automated Lighting Control." Energy and Buildings 38: 814-23.

[10] Konstantoglou, M., and Tsangrassoulis, A. 2016. "Dynamic Operation of Daylighting and Shading Systems: A Literature Review." Renewable and Sustainable Energy Reviews 60: 268-83.

[11] Mahdavi, A. 2011. "People in Building Performance Simulation." In Building Performance Simulation for Design and Operation, edited by Hensen, J., and Lamberts, R. Taylor \& Francis: New York, 56-83.

[12] Tzempelikos, A., and Athienitis, A. K. 2007. "The Impact of Shading Design and Control on Building Cooling and Lighting Demand.” Solar Energy 81: 369-82.

[13] Maslow, A. 1943. "A Theory of Human Motivation." York University, Toronto, Ontario.

[14] Hoes, P., Hensen, J. L. M., Loomans, M. G. L. C., de Vries, B., and Bourgeois, D. 2009. "User Behavior in Whole Building Simulation." Energy and Buildings 41 (3): 295-302.

[15] Peng, C., Yan, D., and Wu, R. 2012. "Quantitative Description and Simulation of Human Behavior in Residential Buildings." Building Simulation 5: 85-94.

[16] Hong, T., et al. 2015. “An Ontology to Represent Energy-Related Occupant Behavior in Buildings Part I: Introduction to the DNAs Framework." Building and Environment: 1-14.

[17] Stack, A., Goulding, J., and Lewis, J. O. 2000. Shading Systems: Solar Shading for the European Climates. Irlanda: E. Comission.

[18] Inkarojrit, V. 2005. Balancing Comfort: Occupants' Control of Window Blinds in Private Offices. Berkeley, CA: University of California.

[19] Tzempelikos, A. 2005. "A Methodology for Integrated Daylighting and Thermal Analysis of Buildings." A thesis of Concordia University, Montreal, Canada.

[20] Kirimtat, A., Koyunbaba, B. K., Chatzikonstantinou, I., and Sariyildiz, S. 2016. "Review fo Simulation Modeling for Shading Devices in Buildings." Renewable and Sustainable Energy Reviews 53: 23-49.

[21] Carvalho, J. P. V. D. 2014. "Simulação do desempenho 
luminoso para salas de aula em Natal-RN." A thesis of Universidade Federal do Rio Grande do Norte, Natal.

[22] Moreno, V. P. C. 2015. "Estratégias para obtenção de adequada iluminação natural em escolas: uma análise de sistemas de aberturas para Natal/RN." A thesis of Universidade Federal Do Rio Grande Do Norte, Natal.

[23] Dias, A. R. D. 2016. "Análise do impacto do sombreamento vegetal no conforto termoluminoso de edificações no clima quente e úmido." A thesis of Universidade Federal do Rio Grande do Norte (UFRN), Natal.

[24] O'Connor, J., Lee, E., Rubinstein, F., and Selkowitz, S. 1997. Tips for Daylighting with Windows-The
Integrated Approach. Berkeley: Ernest Orlando Lawrence Berkeley National Laboratory.

[25] D’Oca, S., Corgnati, S., Pisello, A. L., and Hong, T. Z. 2016. "Introduction to an Occupant Behavior Motivation Survey Framework.” A thesis of CLIMA 2016, Denmark.

[26] ABNT, NBR 15215-4. 2005. "Iluminação natural—Parte 4-Verificação experimental das condições de iluminação interna de edificações-Método de medição." ABNT.

[27] Marsh, A. 2011. Ecotect Analysis 2011. Autodesk.

[28] Rutten, D. 2015. Grasshopper. Google Inc.

[29] Reinhart, C. F. 2010. Daysim 3.1. H. University, Cambridge. 